\title{
Estimating the Impact of Economic Fluctuations on Unemployment in Russian Regions Based on the Okun Model
}

\author{
T. V. Blinova ${ }^{a}, *$, V. A. Rusanovskii ${ }^{b}{ }^{\dagger}$, and V. A. Markov ${ }^{b}$ \\ ${ }^{a}$ Institute of Agrarian Problems, Russian Academy of Sciences, Saratov, 410012 Russia \\ ${ }^{b}$ Yu. Gagarin Saratov State Technical University, Saratov, 410054 Russia \\ *e-mail:tatianvic@mail.ru \\ Received May 11, 2020; revised July 17, 2020; accepted August 12, 2020
}

\begin{abstract}
Based on the modified Okun's model, the article evaluates the impact of changes in production volumes on the dynamics of unemployment in Russia and three regional clusters differing in the unemployment rate and behavioral responses to economic shocks. Assessing the specifications of the basic Okun model on the data of 2010-2020 made it possible to identify a cyclical reaction of the unemployment rate in heterogeneous regional clusters to changes in output volumes.
\end{abstract}

Keywords: Okun's model, econometric assessment, unemployment rate, economic fluctuations, regional clusters

DOI: $10.1134 / \mathrm{S} 1075700721010032$

The baseline scenario with the forecast of world economic development presented in the June report of the World Bank [1] suggests the global GDP contraction by $5.2 \%$ in 2020 , which is the worst for the last eight decades. The predicted decline in the economically developed countries may amount to $7.7 \%$, in the states of the euro area $9.1 \%$, in the United States and Japan $6.1 \%$, and in Russia 6.0\%. Production volumes and per capita incomes in the overwhelming majority of countries are declining, which leads to an increase in unemployment and poverty of the population, provoking a decrease in domestic demand for goods and services. The pace of global economic recovery, according to World Bank forecasts, will be moderate at $4.2 \%$ in 2021, while recovery growth in the Eurozone will reach $4.5 \%$, in the United States $4.0 \%$, in Japan 2.5\%, and in Russia 2.7\% [1]. According to experts, the Russian economy in 2020-2021 will experience three shocks that will adversely affect the dynamics in key indicators of socio-economic development [2]. This implies, firstly, the economic consequences of the coronavirus pandemic, which has swept most countries of the world, including Russia, secondly, the fall in prices for hydrocarbons in world markets, and thirdly, the changing structure and shrinking demand for goods and services due to the global economic downturn and supply chain disruptions. The economic crisis and the recession of the world economy actualize studies of the impact made by the dynamics

\footnotetext{
${ }^{\dagger}$ Deceased.
}

of production volumes on the key indicators of the national labor market.

The relationship between the economic downturn and labor market indicators is studied by both foreign and Russian authors (see, for example, [3-6]). Applying econometric models makes it possible to assess the degree of sensitivity demonstrated by labor market indicators to cyclical fluctuations in macroparameters. The instrumental basis of most investigations is one of the basic modifications of Okun's model; in addition, there are several specifications of the interdependence of unemployment and production volumes described in detail in the literature [7]. Okun found a stable negative relationship between cyclical unemployment (the difference between actual and natural unemployment) and changes in the size of the gap between real and potential GDP [8]. A decrease in demand for goods and services during an economic recession reduces the demand for labor, which is a derivative factor undermining employment and forming the prerequisites for an increase in unemployment. Rising cyclical unemployment, in turn, widens the gap between real and potential GDP, as the "underproduction" of goods and services increases. There are not only economic but also social costs of cyclical unemployment: stratification of the population in terms of income, growing social tension, increased morbidity, crime, etc.

Cyclical fluctuations in output in percentage terms exceed fluctuations in the unemployment rate and output per worker during a recession falls along with a decline in production. In Russia, the drop in output is 
incomparably greater than the scale of the decline in employment and the growth rate of unemployment for special reasons. The analysis of the Russian labor market carried out by various authors shows that with a decline in demand for labor, not only the number of employed decreases but also the hours of work and real incomes of the population, primarily wages, also decrease. The researchers emphasize that, adapting to negative economic shocks, the Russian labor market reacts "not so much with an increase in unemployment, but with a reduction in the duration of working hours and a decrease in real wages" [9, p. 251].

Despite numerous scientific publications devoted to various aspects of the "output-unemployment" relationship, the behavioral reactions of heterogeneous regional labor markets to economic fluctuations have been studied insufficiently. This study expands on the approaches presented in the literature, taking into account the unique diversity of Russian regions and the high heterogeneity of the Russian labor market.

The purpose of the study is to assess the impact of changes in output volumes on the performance of the unemployment rate in three groups of Russian regions, differing both in the unemployment rate and in their behavioral responses to shocks.

The study used official data from the Federal State Statistics Service [10] and data from the Ministry of Economic Development of the Russian Federation [11]. The sample includes 79 federal subjects of the Russian Federation ${ }^{1}$. The study period is 2010 to the first quarter of 2020, and quarterly data are used ${ }^{2}$. We consider the change in the national labor market after the economic shock of the global recession (20082009) and before the onset of a new crisis caused by the consequences of the COVID-19 epidemic. The rate of change in gross domestic product and gross regional product is determined based on the annual and quarterly indices of the physical volume of production. The estimation of regional unemployment rates is based on the methodology of the International Labor Organization (ILO), and the value of the gross regional product is based on the system of national accounts (SNA). The share of the regions included in the sample is $99 \%$ of Russia's GDP, and in the number of unemployed, counted according to the ILO methodology, exceeds $96 \%{ }^{3}$. For the grouping of regions, a specially compiled algorithm of cluster analysis is proposed, which allows taking into account interregional

\footnotetext{
${ }^{1}$ The sample does not include Sevastopol and the Republic of Crimea due to the lack of data until 2014, the Chechen Republic. The Nenets, Khanty-Mansi, and Yamalo-Nenets Autonomous Districts are considered as part of the corresponding federal subjects of the Russian Federation.

2 Unified interdepartmental information statistical system of Rosstat. https://www.fedstat.ru/indicator/43062\#

3 According to Rosstat data (https://fedstat.ru/indicator/33414), 145009 people failed to be included in the sample out of 3465000 unemployed in Russia in 2019.
}

differences, heterogeneous structure, and heterogeneity of behavioral reactions of regional labor markets.

Modifications of Okun's model. It is known that Okun proposed several options for studying the relationship between output and unemployment, considering both direct and inverse relationships. In modern scientific literature, various modifications of Okun's model are discussed and used, one of which is termed as the "gap version", the other is called "difference" reflecting the relationship between the "first differences". Dynamic models are considered, as well as modifications with lagging variables or taken in logarithmic form. In the "discontinuous" modification of the model, the real GDP is compared with the potential (output gap), and the actual unemployment with its natural or target level. The "output gap" for the Russian economy has been repeatedly assessed using the Kalman, Hodrick-Prescott and other filters [12, 13]. Measuring the natural unemployment rate, which is important for evaluating Okun's model in the gap version, presents a certain difficulty. The approaches to the analysis and assessing the natural level of unemployment existing in the literature are considered in the Russian and foreign literature [14-16]. The tools for measuring the natural rate of unemployment most often used by the authors include the Phillips curve, the Beveridge curve, and various filters. It should be noted right away that the relationship between the growth (decline) in production and the deviation of actual unemployment from its natural level is mediated by the impact made by many other factors that reflect the development specifics of the country and its regions.

Another modification of Okun's model reflecting the relationship of first differences involves the assessment of the regression between the increase in the unemployment rate and the rate of increase in output. In the modification, which we will use to solve the set problems, the variables are taken in a logarithmic form, which offers certain advantages, since it allows avoiding distortions caused by deviations in the regional values of the unemployment rate and the rate of production growth from the normal distribution law for a set of regions [17]. Based on the modified Okun model [Okun, 1962], the presence and degree of the sensitivity displayed by the labor market to the business cycle are assessed [18, 19]. The model has the form

$$
d U_{i t}=\alpha_{i}+\beta_{i} d G_{i t}+e,
$$

where $d U_{i t}$ is the absolute change in the unemployment rate in the region $i$ over the period $t ; \beta_{i}$ designates the Okun coefficient, which in the model has a negative value, reflecting an increase in unemployment during a reduction in production and a decline in economic growth; $d G_{i t}$ stands for production growth rate in the region $i$ over the period $t$ as a percentage; $\alpha_{i}$ is the parameter reflecting the specifics of the region $i$ and is to be assessed; $e$ denotes a random variable. 
Table 1. Composition of regional clusters (clubs) of the Russian Federation, 2010-2019

\begin{tabular}{c|c|l}
\hline Club & Number of regions & \multicolumn{1}{c}{ Composition of the regions } \\
\hline 1 & 9 & $\begin{array}{l}\text { Republics: Kabardino-Balkar, Karachai-Cherkessia, Altai, Dagestan, Ingushetia, Kalmykia, } \\
\text { Tyva, North Ossetia-Alania, Transbaikalia. } \\
\text { Republics: Adygeia, Bashkortostan, Buryatia, Karelia, Komi, Mari El, Sakha (Yakutia), Kha- } \\
\text { kassia, Chuvashia. } \\
\text { Oblasts: Arkhangelsk, Astrakhan, Volgograd, Vologda, Irkutsk, Kaliningrad, Omsk, Kem- } \\
\text { erovo, Kirov, Kurgan, Murmansk, Novosibirsk, Orel, Pskov, Rostov, Sakhalin, Sverdlovsk, } \\
\text { Smolensk, Tomsk, Chelyabinsk. Krais: Altai, Perm, Primorskii. Jewish Autonomous Oblast } \\
\text { Moscow, St. Petersburg. Republics: Tatarstan, Mordovia, Udmurtia.Oblasts: Amur, Bel- } \\
\text { gorod, Bryansk, Vladimir, Voronezh, Ivanovo, Kaluga, Kostroma, Kursk, Leningrad, } \\
\text { Lipetsk, Magadan, Moscow, Nizhni Novgorod, Novgorod, Orenburg, Penza, Ryazan, } \\
\text { Samara, Saratov, Tambov, Tver, Tula, Tyumen. Yaroslavl. Krais: Kamchatka, Krasnodar, } \\
\text { Krasnoyarsk, Stavropol, Khabarovsk. Chukotka Autonomous District. }\end{array}$ \\
\hline
\end{tabular}

Source: the authors' calculations based on the data of [10].

The modified Okun model was estimated for a sample of 79 regions of the Russian Federation using quarterly and annual data. Panel regression clarifies the parameters of the strength of the impact made by economic shocks on unemployment in the regional context:

$$
d U_{i t}=\alpha_{i} R_{i}+\beta_{i} R_{i} d G_{i t}+e
$$

where $d U_{i t}$ is the change in the unemployment rate of the region $i$ over the period $t ; \beta_{i}$ is the Okun coefficient for the $i$ th territory; $R_{i}$ stands for dummy variable reflecting regional differences in unemployment; and $d G_{i t}$ is the production growth rate as a percentage [19]. In the panel sample, the observation units are regions. Panel regressions are based on logarithmic output growth and unemployment rate variables. Modifications using the logarithms of the unemployment rate and the output growth rate are widely used in scientific research $[3,17]$.

$$
\ln \left(U_{i t}\right)=\alpha+\beta \ln \left(G_{i t}\right)+e,
$$

where $U_{i t}$ is the unemployment rate in the region $i$ in the year $t ; G_{i t}$ designates the growth rate (production index) in the region $i$ in the year $t$. The parameters of the model (3) were estimated using the $O L S$ least squares method.

Clusterization of regions. The unemployment rate in the Russian labor market is characterized by high interregional differentiation, which decreases over the period of recession and increases with the beginning of economic growth [20-22]. In order to form relatively homogeneous groups, a cluster analysis of Russia's regions included in the sample by the unemployment level ${ }^{4}$ was carried out.

\footnotetext{
${ }^{4}$ The distance between clusters was calculated by the Ward method, the objective function was the summed squares of the distances between the elements and the cluster's "center of gravity" using the Euclidean metric.
}

Hierarchical clustering step by step united regions similar in quarterly dynamics of the unemployment rate in 2010-2019. Note that quarterly data make it possible to obtain clusters (clubs) of regions in the Russian Federation, similar in the cyclical parameters of the unemployment rate. The employed K-means method, widely used in the methodology of cluster analysis, made it possible to minimize differences within clusters and maximize variability between clusters; Euclidean distances describing the quality of clustering are presented in the Appendix (Table). As a result of the hierarchical clustering of the RF regions by the level and dynamics of quarterly unemployment rates for 2010-2019, three groups of regions or three clubs have been formed (Table 1).

The identified clusters (clubs) differ not only in the unemployment rate but also in the measure of the composition heterogeneity associated with the deviations of the unemployment rate regional values from the average for the cluster (Table 2).

Table 2. Coefficient of variation in regional values of the unemployment rate within clubs, 2011-2019, \%

\begin{tabular}{c|c|c|c}
\hline Year & 1 club & 2 club & 3 club \\
\hline 2011 & 30 & 10 & 19 \\
2012 & 32 & 9 & 21 \\
2013 & 32 & 4 & 27 \\
2014 & 31 & 7 & 28 \\
2015 & 30 & 5 & 30 \\
2016 & 30 & 5 & 25 \\
2017 & 31 & 5 & 25 \\
2018 & 31 & 5 & 26 \\
2019 & 31 & 5 & 26 \\
\hline
\end{tabular}

Source: the authors' calculations based on the data of [10].

Vol. 32 No. $1 \quad 2021$ 
Table 3. Okun coefficient: comparison of club parameters, 2010-2020

\begin{tabular}{c|c|c|c}
\hline Cluster (club) & Average unemployment level $U, \%$ & Average production growth rate $G, \%$ & Regression coefficient $\beta^{*}$ \\
\hline 1 & 14.52 & 102.10 & -0.068 \\
2 & 6.96 & 100.92 & -0.043 \\
3 & 4.66 & 100.99 & -0.062 \\
RF & 6.74 & 101.07 & -0.050 \\
\hline
\end{tabular}

* Values of Okun coefficient for model specifications with logarithms of variables.

Source: the authors' calculations based on the data of [10].

As can be seen from the data of Table 2, the second club is relatively homogeneous. Here, the lowest values of the variation coefficient are noted: $4-10 \%$, and this indicator has not changed over the past five years (5\%). The most heterogeneous in composition is the first club where the values of the variation coefficient reach $30-32 \%$. Among the regions of the third club, the coefficient of variation is also high but the range of its change over the years is wider than in the other clubs (19-30\%).

The quarterly dynamics of the average for each cluster of unemployment rates for 2010-2020, which is shown in the figure, is quite different.

The data in the figure show a different depth of response from the cluster average unemployment levels to economic shocks. The first club is characterized by the highest values and amplitude of fluctuations in the unemployment rate, including the first quarter of 2020. In the third club, they are the lowest. An intermediate position is occupied by the regions of the second club where the amplitude of fluctuations and unemployment rate are higher than in the third club but lower than in the first one.

Model specifications. In our study, Okun coefficients were differentiated as the general ones, when the assessment is performed for the national economy as a whole, and special ones, calculated for individual clusters or regions. The article evaluates both general and special Okun coefficients. For this purpose, for each cluster (club) of regions, a panel regression with fixed effects was built. The following models are obtained as a result of the estimation performed by the ordinary least-squares (OLS) method using quarterly data for the period 2010-2020:

$$
\begin{aligned}
& \text { Club 1: } \ln U=-0.068 * \ln G+2.874 \\
& \text { Club 2: } \ln U=-0.043 * \ln G+2.113 \\
& \text { Club 3: } \ln U=-0.062 * \ln G+1.195
\end{aligned}
$$

The analysis of the club specifications of the model shows that the medium-term Okun coefficient is significant according to the Student's criterion, the models are consistent, and the fixed effects of the regions influence the relationship between unemployment and economic fluctuations. The regions of the cluster with the highest unemployment rate (club 1) have the highest Okun coefficient $(-0.068)$. The model explains about $80 \%$ of fluctuations in the unemploy- ment rate $\left(R^{2}=0.791\right)$. In the third cluster (club 3 ) characterized by a low unemployment rate, the regression coefficient between economic dynamics and fluctuations in the unemployment rate is lower than in the first club $(-0.062)$, as well as the coefficient of determination $\left(R^{2}=0.611\right)$. The lowest values of Okun coefficient $(-0.043)$ are obtained for the second club with a low coefficient of determination $\left(R^{2}=0.481\right)$.

Calculations have shown that the values of Okun coefficient, which measures the cyclical response, for all three clusters and for Russia as a whole have negative signs, which is consistent with the theoretical assumptions of the model and the working hypotheses of this study. From the data in Table 3, it can be seen that for 2010-2020 the average for a sample of 79 regions, with an unemployment rate of $6.74 \%$ and an average annual production growth of $1.07 \%$, the Okun coefficient is -0.050 . Each cluster (club) differs both in the level of unemployment and in the rate of growth (decline) in production. Different values of Okun special coefficients are largely explained by significant differences in the structure of economies and labor markets of the regions included in the clubs. It is also necessary to take into account the unevenness and conditions of the socio-economic and demographic development of Russia's regions. An important role is played by the nature of economic shocks affecting the output-unemployment interaction in different periods.

Interregional differences affect not only unemployment rates but also the behavioral responses of labor market indicators to economic shocks. The regions of the first cluster with a relatively high level of unemployment showed a stronger reaction to the recession and lagging behind the recovery growth, which is explained by the structure of the regional economy with a low share of locomotive industries providing growing demand for labor. Most of the regions of the first cluster are distinguished by a high proportion of young people in the population structure, and young people with no work experience are sensitive to cyclical recession and are at risk in the labor market since in a crisis they are fired first and hired last. A risk factor for the regions of the first cluster is also the share of the rural population that exceeds the national average values, among which unemployment is higher than in cities. Most likely, the real scale of unemployment in the regions of this group is higher 
than statistically measured if we take into account the hidden unemployment. On the other hand, there is a high share of the informal sector here, which restrains the growth of actual unemployment. It is important to understand that 'the existence of hidden unemployment, production and employment of the population in the shadow sector leads to distortions in the studied dependence of the dynamics of GDP and the unemployment rate" [7, p. 484]. High quarterly fluctuations in the unemployment rate within a year are typical of the regions in the first cluster as the most heterogeneous one.

The regions of the third cluster with a relatively low level of unemployment adapted faster both to the crisis situation and to the recovery growth. Unemployment increased over the period of the recession, decreased at the stage of economic growth, remaining at a relatively low level. The lowest unemployment rate over the periods of crises were retained in Moscow and St. Petersburg, which is explained by a higher diversification of the economy, the structure of employment and sources of household income as well as the presence of industries that form a growing demand for labor.

The second cluster is the most homogeneous, and its reaction to cyclical economic shocks as well as the value of the Okun coefficient are close to the national average.

In order to overcome the high interregional contrasts in the Russian labor market, the choice of development and investment priorities should proceed from the tasks, firstly, of ensuring economic growth in the short and medium term, and secondly, of establishing "growth poles" enhancing interregional exchange due to the creation of modern industries, thirdly, taking into account the development peculiarities of specific territories [23, p.7]. The results of the study show that at the level of regional clusters (clubs), different reactions of cyclical unemployment to economic shocks in the country are manifested. In addition to macroeconomic shocks, it is necessary to take into account the impact of sectoral shocks.

The study showed a negative relationship between changes in the gross regional product and the dynamics of the unemployment rate, which confirms Okun's statements. The decline or rise in output explains only a small part, namely, the cyclical component of the change in the unemployment rate. Model calculations made it possible to identify different degrees of the unemployment rate sensitivity to cyclical shocks, which is explained by the institutional, social, economic, and demographic development characteristics of Russian regions. The values of the Okun coefficients for three heterogeneous clusters (clubs) calculated using quarterly time series data in 2010-2020 reflect the behavior peculiarities of local labor markets where enterprises, over the period of the crisis, minimize costs, as already noted, by reducing real wages and working hours rather than by mass layoffs of staff. Our results are consistent with the conclusions of other authors who confirm that "adaptation to a drop in production only to a small extent occurs due to an increase in unemployment" [24, p. 205].

Assessment of the "output-unemployment" relationship reflecting the dependence of the labor market on economic fluctuations is especially relevant in the context of the modern "coronacrisis." The downward economic dynamics in January-May 2020 shows that the COVID-19 pandemic has influenced different segments of the economy to varying degrees, affecting some economic activities more than others. In those regional labor markets where the most "exposed" types of economic activity are concentrated, unemployment increased to a greater extent. The reduction of personnel occurred in the service sector, in transport, in construction, trade, cultural institutions, etc. Hotels and restaurants have suffered due to the collapse of the tourism industry. As a result of a sharp decline in demand for air travel and rail services, the demand for fuel has dropped proportionally. At the same time, judging by the stock quotes, as experts note, the chemical and petrochemical industries suffered to a lesser extent. It is known that after the introduction of a number of social restrictions and the transition of many enterprises to a remote mode of operation, the demand for food delivery services rose sharply, sales of disinfectants and personal protective equipment, medicines and food increased. The downturn in employment and downsizing of staff has largely affected small and medium-sized businesses.

Analysis of the dynamics in the physical volume of output by basic types of economic activity shows that in April 2020 it reached $88.8 \%$ compared to March, in May compared to April, 97.4\% [11] The growth in the number of unemployed, according to preliminary data from Rosstat, in April amounted to $123 \%$ against March 2020, in May, 105\% against April 2020. When compared with the corresponding period of 2019, the growth in unemployment amounted to $120.6 \%$ in April and $132.7 \%$ in May (Table 4).

Registered unemployment in May 2020 compared to 2019 increased 2.8 times.

National labor markets in most countries, including Russia, reacted to a slowdown in growth, and then a decline in production, not only with a drop in employment and an increase in unemployment, but also with a decrease in working hours, shrinking wages, and the abolition of awarding bonuses. Thus, according to the Ministry of Economic Development over the period of the COVID-19 pandemic and the decline in production, real wages in March-April 2020 decreased by $6.3 \%$, the employment rate fell from 59.4\% (March 2020) to 58.4\% in April and $58.3 \%$ in May 2020. The unemployment rate increased from $4.7 \%$ (March) to $5.8 \%$ (April) and $6.1 \%$ (May), while the number of unemployed rose 
Table 4. The number of unemployed aged 15 and over, January-May 2020

\begin{tabular}{|c|c|c|c|c|c|c|}
\hline \multirow[b]{2}{*}{ Month } & \multicolumn{3}{|c|}{ Total number of unemployed } & \multicolumn{3}{|c|}{ Number of registered unemployed } \\
\hline & $\begin{array}{l}\text { thousand } \\
\text { people }\end{array}$ & $\begin{array}{c}\text { in relation to the same } \\
\text { period of } 2019, \%\end{array}$ & $\begin{array}{l}\text { in relation to the previous } \\
\text { period, } \%\end{array}$ & $\begin{array}{l}\text { thousand } \\
\text { people }\end{array}$ & $\begin{array}{c}\text { in relation to the same } \\
\text { period of } 2019, \%\end{array}$ & $\begin{array}{c}\text { in relation to the } \\
\text { previous, } \%\end{array}$ \\
\hline January & 3482 & 95.0 & 100.3 & 700 & 95.4 & 101.2 \\
\hline February & 3425 & 93.7 & 98.4 & 730 & 91.4 & 104.3 \\
\hline March & 3485 & 99.1 & 101.8 & 727 & 88.8 & 99.6 \\
\hline April & 4286 & 120.6 & 123.0 & 1311 & 160.5 & 180.4 \\
\hline May & $4513^{*}$ & 132.7 & 105.3 & 2143 & 280 & 163.5 \\
\hline
\end{tabular}

* Preliminary results.

Source: the authors' calculations based on the data of [11]

from 3.5 million in March to 4.5 million in May 2020 [11]. It should be taken into account that many enterprises are going to maintain the telecommuting mode even after the pandemic is over. Currently, the digitalization of the economy is increasing, the volumes of e-commerce, on-line sales, and other operations are expanding, companies' investments in artificial intelligence have increased, the introduction of which is becoming one of the priority areas of investment.

The labor market and the structure of employment in the near future are in for fundamental changes. It is important to understand that getting out of the pandemic does not mean a return to the previous economic model but a transition to a conceptually different one where the labor market will be based on flexible forms of employment and tools for adjusting to cyclical economic fluctuations, as well as on a new structure of labor demand. Assessing regional values of the Okun coefficient over the period of economic recession and recovery growth requires statistical data for 2020-2021 and conducting research taking into account the socio-economic consequences of the "pandemic crisis" and changes in the model of economic development. Over the period of a cyclical economic recession, a significant increase in unemployment should be expected, since the Okun model suggests a stronger response of the unemployment rate to a recession than to recovery growth.

$$
* * *
$$

The coronavirus pandemic has had a significant impact on the Russian economy; experts predict a deep decline in production, an increase in unemployment in 2020, and a slow recovery growth in 2021. Employment support policy over the period of the economic recession should take into account the high interregional differences in the Russian labor market. The article reveals the features of the behavioral reactions to economic fluctuations displayed by regional labor markets with different levels of unemployment. The research suggests the following conclusions.

First, the values of Okun coefficient calculated for three regional clusters have a negative sign, which confirms the theoretical premises and working hypotheses of the study. At the same time, the interaction of the decline (growth) in production with a change in the unemployment rate in the tool for adjusting to economic shocks is mediated by specific institutional, social, economic, and demographic development features of local labor markets in Russian regions, which affect the degree of their susceptibility to changes in production volumes.

Second, a statistically significant assessment of the impact of the growth rates and decline in production on the change in the unemployment rate was obtained. Estimates of the Okun coefficients for Russia as a whole and for three clusters (clubs) separately show that regional labor markets have different degrees of sensitivity to the decline and growth in production, as well as persistently high (first club) and low (third club) unemployment rates in 2010-2020.

Third, the differences in behavioral reactions of labor market parameters to economic shocks in the regions of Russia were revealed. The regions of the first cluster, with a high level of unemployment, are distinguished by a deeper reaction to the recession and lagging behind the recovery growth. The regions of the third cluster with a low level of unemployment adapted faster both to the situation of the crisis and to the recovery growth. The second cluster is the most homogeneous, and the response to cyclical economic shocks is similar to the average Russian one.

Fourthly, the calculations showed that the values of the Okun coefficients in the context of clusters (clubs), as well as for Russia as a whole, turned out to be relatively low. This means that the Russian labor market has a complex mechanism for adjusting to cyclical economic fluctuations. An increase or 


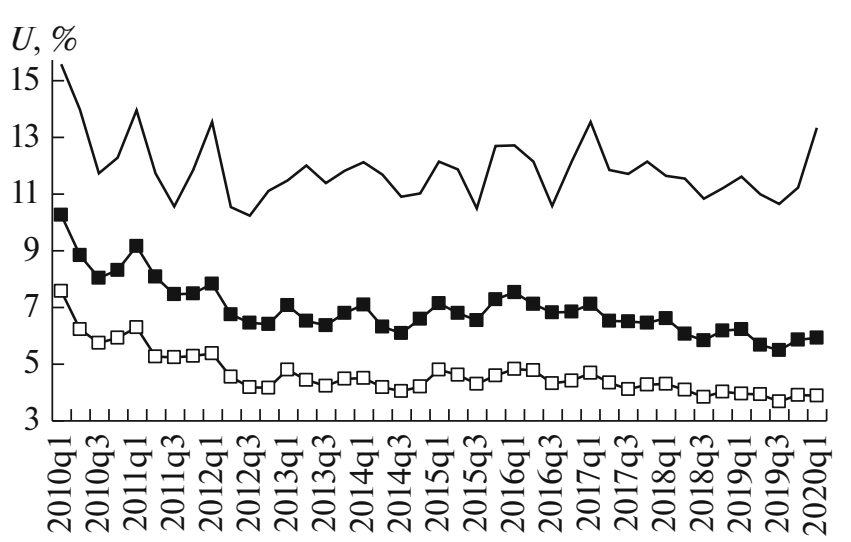

Period

Fig. 1. Average cluster values of the unemployment rate, 2010-2020 (quarterly data):

- club $1,-\square-\operatorname{club} 2,-\square-\operatorname{club} 3$.

Source the authors' calculations based on the data of [10].

decrease in unemployment is only one, but not the only, channel for adaptation to shocks. In turn, the change in the unemployment rate results not only from a decline or growth in production, but is also brought about by other factors, the influence of which, although indirectly, is taken into account by the Okun model.

The results can be used in the development of countercyclical economic policy measures that take into account the current challenges in the labor market. Further research will be aimed at studying the nonlinear asymmetric relationship "output-unemployment" in the context of recession and recovery economic growth in Russia.

APPENDIX

Table

Euclidean distances between clusters

\begin{tabular}{l|c|c|c}
\hline \multicolumn{1}{c|}{ Cluster (club) } & Club 1 & Club 2 & Club 3 \\
\hline Club 1 & 0.00 & & \\
Club 2 & 4.93 & 0.00 & \\
Club 3 & 7.22 & 2.32 & 0.00 \\
\hline
\end{tabular}

Source: calculated by the authors according to Rosstat data [10].

\section{FUNDING}

This work was supported by the Russian Foundation for Basic Research, project no. 20-010-00681).

\section{CONFLICT OF INTEREST}

The authors declare that they have no conflicts of interest.

\section{REFERENCES}

1. Global Economic Prospects (World Bank, Washington, DC, 2020). https://doi.org/10.1596/978-1-4648-1553-9

2. A. L. Vedev, S. M. Drobyshevskii, A. Yu. Knobel', I. A. Sokolov, and P. V. Trunin, "Scenarios for the development of the economic situation in Russia in 2020-2021 and challenges of economic policy," Ekon. Razvit. Ross. 27 (5), 4-23.

3. S. Cazes, Sh. Verick, and F. A. Hussami, "Why did unemployment respond so differently to the global financial crisis across countries? Insights from Okun's law," IZA J. Labor Policy 2, 1-18 (2013).

4. R. Dixon, G. C. Lim, and J. C. Van Ours, "Revisiting the Okun relationship," Appl. Econ. 49 (28), 27492765 (2017).

5. A. Evans, "Okun coefficients and participation coefficients by age and gender," IZA J. Labor Econ. 7 (5), 122 (2018). https://doi.org/10.1186/s40172-018-0065-8

6. M. Maitah, D. Toth, and E. Kuzmenko, "Exploring the relationship between economic growth and employment in the Czech Republic and Belgium," Rev. Eur. Stud. 7 (11), 115-124 (2015).

7. O. V. Akhundova, A. G. Korovkin, and I. B. Korolev, "The relationship between the dynamics of GDP and unemployment: Theoretical and practical aspects," in Scientific Proceedings: Institute of Economic Forecasting, Russian Academy of Sciences (2005), pp. 471-497 [in Russian].

8. A. M. Okun, "Potential GNP: Its measurement and its significance," in Proceedings of the Business and Economic (Stat. Sect., Am. Stat. Assoc., 1962).

9. V. E. Gimpel'son and R. I. Kapelyushnikov, "Russia's model of the labor market: A test of the crisis," Zh. Nov. Ekon. Assots., No. 2, 249-253 (2015).

10. Rosstat: Federal State Statistics Service. https://www.gks.ru.

11. Ministry of Economic Development of the Russian Federation. Business Landscape for May 2020. https://www.economy.gov.ru/material/file/0a16c1bc10412bb6dcabfc834301154b/200618_.pdf.

12. A. V. Zubarev and P. V. Trunin, "The analysis of the dynamics of the Russian economy using the output gap indicator," Stud. Russ. Econ. Dev. 28, 126-132 (2017).

13. S. Sinel'nikov-Murylev, S. Drobyshevskii, and M. Kazakova, "Decomposition of Russia's GDP growth rates in 1999-2014," Ekon. Polit., No. 5, 7-37 (2014).

14. L. Ball and N. G. Mankiw, "The NAIRU in theory and practice,” J. Econ. Perspect. 16 (4), 115-136 (2002).

15. O. V. Akhundova and A. G. Korovkin, "Experience in estimating the natural level of unemployment in Russia's economy," in Scientific Proceedings: Institute of Economic Forecasting, Russian Academy of Sciences (MAKS Press, Moscow, 2006), pp. 488-508 [in Russian]. 
16. O. Blanchard, "Should we reject the natural rate hypothesis?," J. Econ. Perspect. 32 (1), 97-120 (2018).

17. N. O'Higgins, "This time it's different? Youth labour markets during 'the Great Recession'," Comp. Econ. Stud. 54 (2), 395-412 (2012). https://doi.org/10.1057/ces.2012.15

18. H. Boulhol and P. Sicari, "Labour market performance by age groups: A focus on France," OECD Econ. Dep. Work. Pap., No. 1027 (2013).

19. O. Hutengs and G. Stadtmann, "Age- and gender-specific unemployment in Scandinavian countries: An analysis based on Okun's law," Comp. Econ. Stud. 56 (4), 567-580 (2014).

20. Youth Labor Market: Assessment and Modeling of Interregional Differences (Univ. Kn., Moscow, 2016) [in Russian].
21. T. Blinova, V. Markov, and V. Rusanovskiy, "Empirical study of spatial differentiation of youth unemployment in Russia," Acta Oecon. 66 (3), 507-526 (2016).

22. T. V. Blinova, V. A. Markov, and V. A. Rusanovskiy, "Interregional differences of the youth unemployment in Russia: Models of convergence," Ponte J. 73 (8), 202-216 (2017).

23. V. V. Ivanter, O. Dzh. Govtvan', M. S. Gusev, M. Yu. Ksenofontov, D. B. Kuvalin, A. K. Moiseev, B. N. Porfiryev, V. V. Semikashev, M. N. Uzyakov, and A. A. Shirov, "System of measures to recovery of economic growth in Russia," Stud. Russ. Econ. Dev. 29, $1-5$ (2018).

24. E.T. Gurvich and E.S. Vakulenko, "Research of Russia's labor market and economic policy," Zh. Nov. Ekon. Assots., No. 1, 203-212 (2018).

Translated by I. Pertsovskaya 